\title{
Does Salary Discrimination by Nationality Exist? The Case of Nippon Professional Baseball League
}

\author{
Wen-Jhan Jane $^{1 *}$, Sheng-Tung Chen ${ }^{2}$, Min-Hua Kuo ${ }^{3}$ \\ ${ }^{1}$ Department of Economics, Shih Hsin University, Taipei, Taiwan \\ ${ }^{2}$ Department of Public Finance, Feng Chia University, Taichung, Taiwan \\ ${ }^{3}$ Department of Finance, Shih Hsin University, Taipei, Taiwan \\ Email: *krisenwerk@gmail.com
}

Received November 27, 2012; revised December 28, 2012; accepted January 29, 2013

\begin{abstract}
This article focuses on the issue of nationality as related to salary discrimination in the Nippon Professional Baseball (NPB) league. Salary data for 663 players during the period from 2000 to 2008 was collected, and Quantile Regression (QR) was employed to investigate the nationality discrimination in salary. The main finding indicates that, on average, international players were paid $54.7 \%-57.3 \%$ more than domestic players ceteris paribus. QR results show that the positive effect of nationality on salary is larger for players with relatively higher salaries. The finding indicates that an international player's salary premium increases with salary.
\end{abstract}

Keywords: Nippon Professional Baseball; Quantile Regression; Reservation Salary; Salary Discrimination

\section{Introduction}

Due to the rapid progress of information and communication technology (ICT), the Nippon Professional Baseball (NPB) league has begun to expand its global makeup. The ratio of international players has increased steadily from $2.21 \%$ in the 2000 season to $6.55 \%$ in 2008 . As the literature in sports economics has widely examined the question of racial and ethnic salary discrimination, the upsurge in international players in the NPB inspires a new and interesting question about whether salary differentials exist by nationality. That is, whether the NPB differentiates pecuniary treatment between international players and Japan-born players.

International players may fare well relative to native players in Japan. The famous hypothesis of a winner's curse argues that teams may overestimate a player's marginal revenue product (MRP) since limited information and trade uncertainty exists in the labor market [1]. Specifically, when international players have no Japanese baseball experience, NPB teams lack comparative information regarding their true talent and are apt to overestimate their talent, which creates a tendency to overpay international players.

Alternatively, international players may be underpaid, giving the appearance of salary discrimination based on nationality. Teams with limited experience, facing the difficulty of accurately evaluating an international player's talent, may adopt a conservative attitude toward paying

\footnotetext{
"Corresponding author.
}

international players a high salary. Moreover, international players from Asia are apt to accept a discriminatory salary as it is likely higher than that offered in their home countries.

The bulk of the empirical evidence on race or ethnic salary discrimination in professional sports comes from baseball, basketball, football, and hockey [2-4]. The issue of whether nationality-based salary discrimination exists is an emerging issue. Only a few studies, for example $[1,5,6],{ }^{1}$ have examined discrimination by nationality in the NBA and English professional soccer league. The rarity of studies suggests a need for more empirical evidence.

This study investigates the difference in salary between NPB and international players. We attempt to contribute the empirical literature by providing the following work. First, the investigation on the potential difference in salary between local and international players is insufficient when the influx of international players in professional sports has become prevalent during the past decade. Based on salary data in NPB, the relationships between a player's nationality and his salary are investigated. This study provides new evidence on whether there is nationality discrimination in salary in the NPB.

Second, researchers seem to have usually assumed that

${ }^{1}$ Wilson and Ying (2003) examine the influence of the composition of player nationalities on professional football teams from 1997-2000 in the world's five largest football leagues. Eschker et al. (2004) use NBA data to study the winner's curse in hiring international basketball players. Pedace (2008) tests for the existence of nationality discrimination in the English professional soccer league. 
the repressors "only" affect the location of the conditional mean. However, in the analysis of quantile regression, it allows the regressors affect dependent variable at certain values of the regressors. Therefore, the difference of the effects between high-salary and low-salary players' nationality discrimination in salary can be compared.

Third, although there are numerous researches focused on salary discrimination in American and European professional leagues, to the best of our knowledge, this study is the first attempt on measuring the salary discrimination by nationality in professional baseball in Asia. As such, to fill this gap in the literature, we employ data from the NPB to examine these relationships.

The rest of this article is organized as follows. A literature review and introduction of the NPB are in Section 2. Section 3 presents the data and empirical model. Section 4 presents the empirical results and provides related discussion. Finally, the conclusions are summarized in Section 5.

\section{Literature Review of Salary Discrimination and an Introduction of the NPB}

Empirical research of salary discrimination generally shows that, even after controlling for individual performance and player characteristics such as education and experience, blacks have lower earnings levels than whites. The earnings gap between races or ethic groups is commonly attributed to labor market discrimination. Beginning from the seminal model of [7], economists have been concerned with the persistence of labor market discrimination. Research devoted to the issue has investigated persistent salary differentials between equally productive workers of different races.

The treatment of minorities in North American and Europe has been an issue in sports for decades. The bulk of the empirical evidence on salary discrimination in professional sports comes from baseball ([2,8-13]), basketball $([3,14-16])$, football $([4,5,17])$ and hockey $([18,19])$. The most common method is to regress salary (or its log) on a dummy variable for race and a list of productivity indicators. The research has focused heavily on blacks. In some studies, race was broken down into more categories, e.g., Caucasian, Black and Hispanic-Black.

Studies of discrimination in professional baseball mostly focus on Major League Baseball (MLB). One of the first studies is [20]. He found evidence of the existence of employment discrimination in the MLB. ${ }^{2}$ One year later, $[21]^{3}$ had similar findings. These two papers, util-

\footnotetext{
${ }^{2}$ In Scully's sample, nonwhites also received higher pay for better performance and more experience. Nonwhites may be suffering discrimination, even though they are paid more, if the differences in salary do not fully reflect the differences in performance and experience. ${ }^{3}$ Pascal and Rapping (1972) found that there was a significant negative effect for Latin non-pitchers and a significant negative effect for white pitchers.
}

izing primarily data from the sixties, focused on earnings and productivity differences between players according to color. [8] argued that black athletes were restricted to certain positions, and they were paid less for their performance. After that, [2] focused on the transition period (1947-1959) to study the impact of differing responses by individual teams to industry desegregation. They found low discriminators (i.e., teams willing to employ black players) obtained a competitive advantage in the MLB relative to other teams. They were able to win more games, acquire quality players at a lower cost, and increase annual admissions revenue. These gains offered an incentive for teams to desegregate. Later, [11-12] indicated that there was a significant shortfall in Caucasian salaries in the MLB, controlling for measured productivity.

Although $[11,12]$ found significant white salary shortfalls in regressions, [22], using data similar to that of Christiano's 1988 study, but with a longer list of performance measures, found only small, statistically insignificant racial differences. Other research, such as $[9,10]$ also found no significant evidence of racial discrimination in professional baseball salaries. More recent work, such as [13], found league expansion and free agency eligibility did bring relief from discrimination.

Among previous studies, several later studies suggest that racial salary discrimination in the major leagues was either nonexistent or slight (see, for example, [9,10,13,22]). ${ }^{4}$ The salary discrimination literature has tapered off since the early 1980s, perhaps because the issue seems to have been resolved in the MLB. However, compared to the abundant research in the MLB, the Japanese league has never been examined. The issue of salary discrimination in the NPB needs to be investigated.

Baseball is the most popular sport in Japan, and their national team is one of the best in the world. The professional baseball association, the NPB, was organized in 1950 and won the first (2006) and second (2009) World Baseball Classic championship. Like the MLB, the NPB has two leagues. They are the Central and Pacific Leagues, each consisting of six teams. ${ }^{5}$ The NPB player's data offers an opportunity for the study of salary discrimination by nationality. Foreign players have been

\footnotetext{
${ }^{4}$ Other discrimination issues in professional sports include the following. Hamilton (1997) and Gius and Johnson (1998) test for salary discrimination in the NBA; Jones, Nadeau and Walsh (1999) perform a similar analysis for the NHL. Eschker et al. (2004) use NBA data to study the winner's curse in hiring international basketball players. Other studies have analyzed the draft mechanism in choosing talent. Hendricks et al. (2003) analyze uncertainty, option value, and statistical discrimination in the NFL draft. Groothuis, Hill and Perri (2007) analyze early entry in the NBA draft, while Lavoie (2003) focuses on discrimination in the NHL draft.

${ }^{5}$ The Pacific League uses the designated hitter style of play. The season's length is eight months. Games begin in spring (late March) and the championship is held in October. During the regular season, teams play 136-144 games as compared to American major league teams which play 162 games.e pitchers.
} 
prominent throughout the history of the NPB, though they are a minority. On average, $4.26 \%$ of NPB players are foreigners, but the ratio rose over the last decade. Figure 1 summarizes the ratio of international players in the NPB from 2000 to 2008.

\section{Empirical Methodology and Data Description}

In this paper two methods are employed to estimate the effect of nationality. One uses the OLS regression and the other uses the Quantile Regression (QR) proposed by [23]. The former is a standard approach to estimate unknown parameters. However, this approach only measures the "average" behavior of a conditional distribution without providing enough information of the entire conditional distribution. To address this problem, QR is used to estimate various coefficients on their conditional distribution.

The OLS regression model is listed in Equation (1). Vector $\varepsilon$ denotes the error term. Explanatory variables include player's nationality dummy (Nat), a matrix of player's performance variables $(P)$, and player-specific and team-specific characteristics $(C)$.

$$
\log S a l=\alpha+N a t \beta+P \gamma+C \eta+\varepsilon
$$

The matrix of $C$ includes the player's tenure (TEN), player's square term of tenure (SQTEN), height (Height), weight (Weight), dummies for the player's way of pitching (PIT) and hitting (HIT), player's position dummies (POS), team dummies (TEAM), and league dummies (L). ${ }^{6}$

$P$ includes the batters' and pitchers' parts. For a comprehensive investigation, all the player's performance indices (17 indices for batters and 16 for pitchers) are included in different regressions. Batters' indices include games played (GP), runs batted in (RBI), home runs (HR), total bases (TB), etc. Pitchers' indices include Wins (W), games started (GS), home runs allowed (HRA), strikeouts (SO), wild pitches (WP), etc. The complete variable list and descriptions are in Table 1.

QR permits the estimation of various effects on the conditional distribution, provides richer information, plus a more comprehensive and robust analysis. Therefore, the QR is employed to get a complete picture of the conditional distribution on a player's salary. Equation (1) can be re-written as:

$$
\log S a l=\alpha+N a t \beta_{q}+P \gamma_{q}+C \eta_{q}+\varepsilon_{q}
$$

where $\beta_{q}$ is the coefficient on nationality. $\gamma_{q}$ and $\eta_{q}$ are vectors of coefficients on individual performance and

${ }^{6}$ One dummy is used to separate 2 ways of pitching (PIT), e.g. righthanded and left-handed pitches. Meanwhile, another 2 dummies (HIT) are used to separate 3 ways of batting. They include right-side, left-side, and switch-hitting. Three position dummies (POS) are used to describe 4 positions including pitcher, catcher, infielder, and outfielder.

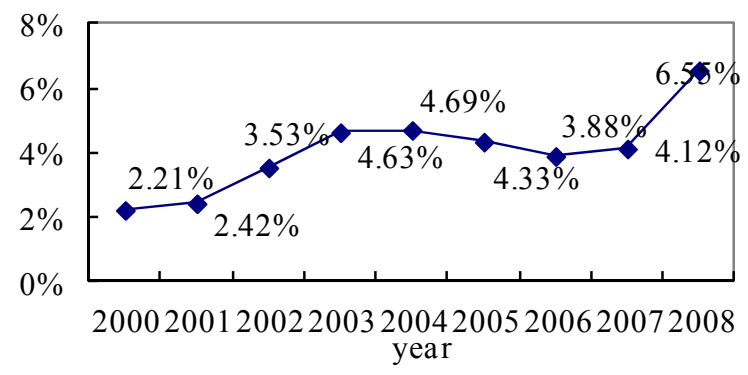

Figure 1. Ratio of international players in the NPB by year.

player/team specific characteristics, which are associated with the $q$-th quantile, and $\varepsilon_{q}$ is an unknown error term. It is assumed that $\varepsilon_{q}$ satisfies the constraint,

Quant $_{q}\left(\varepsilon_{q} \mid N a t, P, C\right)=0$. To obtain the estimators of $\left(\beta_{q}, \gamma_{q}, \eta_{q}\right)$, given a particular value for $q$ :

$\left(\hat{\beta}_{q}, \hat{\gamma}_{q}, \hat{\eta}_{q}\right)$

$=\arg \min _{\beta_{q}, \gamma_{q}, \eta_{q}}\left(\sum_{\log S a l \geq N a t \beta+P \gamma+C \eta} q|\log S a l-N a t \beta-P \gamma-C \eta|\right.$ (3)

$\left.+\sum_{\log S a l<N a t \beta+P \gamma+C \eta}(1-q)|\log S a l-N a t \beta-P \gamma-C \eta|\right)$

Which can be shown in the form of a linear programming problem and is computationally straightforward. The special case $q=0.5$ is referred to as the median regression estimator. A more detailed discussion can be found in [24].

An unbalanced panel of salary data from 14 NPB teams including 322 batters and 341 pitchers over the 9 -year period from 2000 to 2008 was collected. Salary data was obtained from "Professional Baseball Players 2001 to 2009", edited by the Japan Professional Baseball Committee. The sample of hitters and pitchers who played during the period has been chosen according to the following criteria: the hitter's total number of slugging episodes and the number of times at bat must not be zero, the pitcher must have confronted more than one hitter, and professional minor league players are not included. The descriptive statistics are listed in Table 1. This study notes that $4.26 \%$ of NPB players are international players. The mean annual salary for international players is 133.7 million Yen, which is $51 \%$ greater than that of Japanese players. $^{7}$

Previous researches use regression to uncover salary discrimination against specific races or groups, but there is no related empirical evidence for reference in the Japanese professional sports market. Therefore, the coefficient of nationality dummy $(\beta)$ is not expected to be positive or negative. When comparing the Japanese and foreigners' average salaries, the former's average salary is 89 million Yen and the latter is 134 million Yen. A

${ }^{7}$ The average exchange rate during our data period (2000-2008) was 1US\$ $=114.5822$ Yen. 
Table 1. Descriptive Statistics of the Data $(n=2442)$.

\begin{tabular}{|c|c|c|c|c|c|c|c|}
\hline Variable & Description & Mean & Std. Dev. & Variable & Description & Mean & Std. Dev \\
\hline $\mathrm{Sal}^{\mathrm{a}}$ & Player's salary & 90.600 & 2193.905 & Nat & $\begin{array}{l}1 \text { for foreigners and } 0 \\
\text { for Japanese }\end{array}$ & 0.043 & 0.202 \\
\hline $\mathrm{SalF}^{\mathrm{a}}$ & Foreigner's salary & 133.731 & 165.023 & $\mathrm{SalJ}^{\mathrm{a}}$ & Japanese salary & 88.854 & 2244.302 \\
\hline \multirow[t]{2}{*}{$\mathrm{SalB}^{\mathrm{a}}$} & Batter's salary & 142.550 & 3113.509 & $\mathrm{SalP}^{\mathrm{a}}$ & Pitcher's salary & 39.538 & 51.209 \\
\hline & \multicolumn{7}{|c|}{ Player's Characteristics } \\
\hline TEN & Player's tenure & 4.505 & 2.829 & & & & \\
\hline \multirow[t]{2}{*}{ Height } & Player's height & 180.150 & 4.624 & Weight & Player's weight & 81.015 & 7.090 \\
\hline & \multicolumn{7}{|c|}{ Players' Performance } \\
\hline Batter's & Performance & & & Pitcher's & Performance & & \\
\hline GP & Games played & 67.578 & 47.255 & GS & Games started & 23.544 & 17.492 \\
\hline PA & Plate appearance & 218.127 & 205.981 & $\mathrm{TBF}$ & Total batters faced & 248.186 & 217.840 \\
\hline $\mathrm{AB}$ & At bats & 194.063 & 182.966 & HA & Hits against & 57.96 & 50.987 \\
\hline $\mathrm{SAC}$ & Sacrifice bunts & 4.027 & 6.726 & HRA & Home runs allowed & 6.173 & 5.853 \\
\hline $\mathrm{SacF}$ & Sacrifice flies & 1.281 & 1.762 & $\mathrm{BBP}$ & Bases on balls & 18.529 & 15.705 \\
\hline $\mathrm{BB}$ & Bases on balls & 16.487 & 19.339 & HBP & Hit by pitch & 2.388 & 2.585 \\
\hline SOB & Strikeouts & 35.535 & 32.653 & WP & Wild pitches & 1.909 & 2.329 \\
\hline SB & Stolen bases & 3.460 & 6.377 & $\mathrm{Bk}$ & Balks & 0.167 & .6391 \\
\hline CS & Caught stealing & 1.656 & 2.531 & Runs & Runs allowed & 26.990 & 23.141 \\
\hline RBI & Runs batted in & 23.678 & 27.929 & IP & Innings pitched & 58.068 & 52.368 \\
\hline Table 1 & Continued & & & & & & \\
\hline RS & Runs scored & 25.644 & 27.447 & ERA & Earned run average & 4.893 & 5.193 \\
\hline $\mathrm{SH}$ & Safety hits & 53.088 & 54.585 & SOP & Strikeouts & 45.693 & 43.339 \\
\hline DB & Doubles & 9.201 & 10.049 & SV & Saves & 1.509 & 5.832 \\
\hline ThirdB & Triples & 0.862 & 1.521 & $\mathrm{SHO}$ & Shutouts & .209 & .612 \\
\hline $\mathrm{HR}$ & Home runs & 5.706 & 9.013 & $\mathrm{~W}$ & Wins & 3.322 & 3.914 \\
\hline $\mathrm{TB}$ & Total bases & 81.133 & 87.750 & $\mathrm{~L}$ & Loses & 3.096 & 3.217 \\
\hline $\mathrm{BA}$ & Batting average & 0.228 & 0.102 & & & & \\
\hline
\end{tabular}

Notes: ${ }^{\mathrm{a}}$ The unit is a million Yen, and the average exchange rate during the data period $(2000-2008)$ was 1 US $\$=114.5822$ Yen.

foreign player gets about 1.5 times more than a Japanese player on average, which is a quite large difference. If the local and foreign players' performance is similar, the difference may cast some preliminary doubt on the premise of nationality discrimination. However, a more in-depth analysis and more convincing evidence are required.

\section{Empirical Results and Discussion}

The results of OLS regression and QR for all players are listed on Table 2. Each regression consists of three models. The first column reports the results of the basic model in OLS regression, and the second one shows the results of the basic model which controlled the player's position, pitch, and hit dummies. The third column lists the results of the complete model except for the player's performance. The results of $\mathrm{QR}$ are also reported in the same formation. Likewise, the results of batter's and pitcher's regression controlling the individual performance are listed in Tables $\mathbf{3}$ and $\mathbf{4}$.

In Tables 2-4, all coefficients of nationality are significant and positively related to salary. It indicates that international players earn more than Japanese ceteris paribus. This evidence indicates that international play- 
Table 2. Estimation results of ols and quantile regressions (full sample, $n=2442)$.

\begin{tabular}{|c|c|c|c|c|c|c|c|c|c|c|c|c|}
\hline \multirow[t]{2}{*}{ LogSal } & \multicolumn{3}{|c|}{ OLS } & \multicolumn{9}{|c|}{ Quantile } \\
\hline & & & & & 25 th & & & 50th & & & 75 th & \\
\hline Nat & $\begin{array}{l}0.563^{* * *} \\
(0.043)\end{array}$ & $\begin{array}{l}0.547^{* * *} \\
(0.043)\end{array}$ & $\begin{array}{l}0.573^{* * *} \\
(0.042)\end{array}$ & $\begin{array}{l}0.529^{* * *} \\
(0.080)\end{array}$ & $\begin{array}{l}0.486^{* * *} \\
(0.040)\end{array}$ & $\begin{array}{l}0.485^{* * *} \\
(0.092)\end{array}$ & $\begin{array}{l}0.617^{* * *} \\
(0.047)\end{array}$ & $\begin{array}{l}0.628^{* * *} \\
(0.050)\end{array}$ & $\begin{array}{l}0.662^{* * *} \\
(0.091)\end{array}$ & $\begin{array}{l}0.773^{* * *} \\
(0.091)\end{array}$ & $\begin{array}{l}0.722^{* * *} \\
(0.054)\end{array}$ & $\begin{array}{l}0.698^{* * *} \\
(0.075)\end{array}$ \\
\hline TEN & $\begin{array}{l}0.095^{* * *} \\
(0.010)\end{array}$ & $\begin{array}{l}0.101^{* * *} \\
(0.010)\end{array}$ & $\begin{array}{l}0.099^{* * *} \\
(0.010)\end{array}$ & $\begin{array}{l}0.023^{* *} \\
(0.010)\end{array}$ & $\begin{array}{l}0.030^{* *} \\
(0.012)\end{array}$ & $\begin{array}{l}0.036^{* * *} \\
(0.012)\end{array}$ & $\begin{array}{l}0.093^{* * *} \\
(0.010)\end{array}$ & $\begin{array}{l}0.096^{* * *} \\
(0.012)\end{array}$ & $\begin{array}{l}0.099^{* * *} \\
(0.011)\end{array}$ & $\begin{array}{l}0.169^{* * *} \\
(0.013)\end{array}$ & $\begin{array}{l}0.158^{* * *} \\
(0.011)\end{array}$ & $\begin{array}{l}0.156^{* * *} \\
(0.018)\end{array}$ \\
\hline SQTEN & $\begin{array}{c}-0.002^{* * *} \\
(0.001)\end{array}$ & $\begin{array}{c}-0.003^{* * *} \\
(0.001)\end{array}$ & $\begin{array}{l}-0.002^{*} \\
(0.001)\end{array}$ & $\begin{array}{l}0.003^{* * *} \\
(0.001)\end{array}$ & $\begin{array}{l}0.002^{* *} \\
(0.001)\end{array}$ & $\begin{array}{l}0.002^{* *} \\
(0.001)\end{array}$ & $\begin{array}{l}-0.002^{*} \\
(0.001)\end{array}$ & $\begin{array}{l}-0.002 \\
(0.001)\end{array}$ & $\begin{array}{l}-0.002^{*} \\
(0.001)\end{array}$ & $\begin{array}{c}-0.006^{* * *} \\
(0.001)\end{array}$ & $\begin{array}{c}-0.006^{* * *} \\
(0.001)\end{array}$ & $\begin{array}{c}-0.006^{* * *} \\
(0.001)\end{array}$ \\
\hline Table 2 & Continued & & & & & & & & & & & \\
\hline Height & $\begin{array}{c}-0.015^{* * *} \\
(0.002)\end{array}$ & $\begin{array}{c}-0.017^{* * *} \\
(0.002)\end{array}$ & $\begin{array}{c}-0.019^{* * *} \\
(0.002)\end{array}$ & $\begin{array}{c}-0.019^{* * *} \\
(0.003)\end{array}$ & $\begin{array}{c}-0.023^{* * *} \\
(0.002)\end{array}$ & $\begin{array}{c}-0.021^{* * *} \\
(0.003)\end{array}$ & $\begin{array}{c}-0.016^{* * *} \\
(0.002)\end{array}$ & $\begin{array}{c}-0.0188^{* * *} \\
(0.003)\end{array}$ & $\begin{array}{c}-0.023^{* * *} \\
(0.002)\end{array}$ & $\begin{array}{c}-0.018^{* * *} \\
(0.004)\end{array}$ & $\begin{array}{c}-0.020^{* * *} \\
(0.004)\end{array}$ & $\begin{array}{c}-0.021^{* * *} \\
(0.003)\end{array}$ \\
\hline Weight & $\begin{array}{l}0.012^{* * *} \\
(0.001)\end{array}$ & $\begin{array}{l}0.013^{* * *} \\
(0.001)\end{array}$ & $\begin{array}{l}0.015^{* * *} \\
(0.002)\end{array}$ & $\begin{array}{l}0.011^{* * *} \\
(0.001)\end{array}$ & $\begin{array}{l}0.011^{* * *} \\
(0.002)\end{array}$ & $\begin{array}{l}0.012^{* * *} \\
(0.002)\end{array}$ & $\begin{array}{l}0.011^{* * *} \\
(0.002)\end{array}$ & $\begin{array}{l}0.012^{* * *} \\
(0.002)\end{array}$ & $\begin{array}{l}0.016^{* * *} \\
(0.002)\end{array}$ & $\begin{array}{l}0.014^{* * *} \\
(0.003)\end{array}$ & $\begin{array}{l}0.016^{* * *} \\
(0.003)\end{array}$ & $\begin{array}{l}0.019^{* * *} \\
(0.003)\end{array}$ \\
\hline PIT & & YES & YES & & YES & YES & & YES & YES & & YES & YES \\
\hline HIT & & YES & YES & & YES & YES & & YES & YES & & YES & YES \\
\hline POS & & YES & YES & & YES & YES & & YES & YES & & YES & YES \\
\hline TEAM & & & YES & & & YES & & & YES & & & YES \\
\hline League & & & YES & & & YES & & & YES & & & YES \\
\hline Year & & & YES & & & YES & & & YES & & & YES \\
\hline _cons & $\begin{array}{l}4.737^{* * *} \\
(0.344)\end{array}$ & $\begin{array}{l}4.713^{* * *} \\
(0.351)\end{array}$ & $\begin{array}{l}5.020^{* * *} \\
(0.351)\end{array}$ & $\begin{array}{l}5.496^{* * *} \\
(0.399)\end{array}$ & $\begin{array}{l}6.040^{* * *} \\
(0.292)\end{array}$ & $\begin{array}{l}5.589^{* * *} \\
(0.436)\end{array}$ & $\begin{array}{l}4.871^{* * *} \\
(0.388)\end{array}$ & $\begin{array}{l}5.130^{* * *} \\
(0.428)\end{array}$ & $\begin{array}{l}5.633^{* * *} \\
(0.377)\end{array}$ & $\begin{array}{l}5.083^{* * *} \\
(0.617)\end{array}$ & $\begin{array}{l}5.182^{* * *} \\
(0.613)\end{array}$ & $\begin{array}{l}5.089^{* * *} \\
(0.498)\end{array}$ \\
\hline (Pseudo)- $\mathrm{R}^{2}$ & 0.251 & 0.274 & 0.313 & 0.117 & 0.132 & 0.157 & 0.166 & 0.182 & 0.209 & 0.189 & 0.213 & 0.241 \\
\hline
\end{tabular}

Notes: (a) Standard errors are in parenthesesp; (b) ${ }^{* * *}$ denotes significance at the $1 \%$ level, ${ }^{* *}$ denotes significance at the $5 \%$ level, and ${ }^{*}$ denotes significance at the $10 \%$ level.

ers fared better relative to Japanese players. The treat ment of the minority in the NPB is a kind of inverse discrimination, and the hypothesis of a winner's curse, which argues that international players are overpaid because of the employer's limited information is supported.

Uncertainty over a player's trade potential in the labor market can result in a nationality effect on salary. The most important policy in professional sports regarding a fair labor market is free agency. Japanese professional baseball started their system of free agency in November 1993. The qualification to be a MLB free agent is a six-year tenure in "the league", but, in the NPB, it is an eight-year tenure in "a team". ${ }^{8}$ Different from the MLB, there are two categories of free agency for domestic and international players in the NPB. Domestic players quailfying for free agency can only move to other NPB teams, while international players qualifying for free agency are free to market themselves worldwide. The employer pool

\footnotetext{
${ }^{8}$ One year of service time is defined as 145 days on the team's top roster. Time spent in a farm team or on an injured list does not count in the service time toward free agency. The regulation of eight-year tenure was shortened to seven years after 2007.
}

which international players can access for bargaining is much bigger than that of domestic players, so uncertainty over an international player's trade ability is much higher than that of a Japanese player for an employer. Thus, international players are apt to receive a better salary.

Moreover, what's interesting is that the coefficients for higher quantiles are consistently larger than for lower quantiles in Tables 2 and 3. In other words, the positive effect of nationality on salary is larger for players with relatively high salary. However, the results of QR regressions for pitchers do not show the same results.

As to the tenure effect, the coefficients of tenure are consistently significant and positively related to salary, but its square term is not consistently negative as related to the salary for different quantiles. In Table 2, the coefficients of tenure's square term (SQTEN) are significantly negative for the high and median quantiles, but they are significantly positive for the low quantile. That is, on average, a player's salary increases at a decreasing rate as tenure increases. Take the regressions for batters in Table 3 as an example, TEN takes the value 24.75 
Table 3. Estimation Results of OLS and Quantile Regressions for Batters $(n=1212)$.

\begin{tabular}{|c|c|c|c|c|c|c|c|c|c|c|c|c|}
\hline \multirow[t]{2}{*}{ LogSal } & \multicolumn{3}{|c|}{ OLS } & \multicolumn{9}{|c|}{ Quantile } \\
\hline & & & & & 25 th & & & 50 th & & & 75 th & \\
\hline Nat & $\begin{array}{l}0.369^{* * *} \\
(0.054)\end{array}$ & $\begin{array}{l}0.373^{* * *} \\
(0.055)\end{array}$ & $\begin{array}{l}0.406^{* * *} \\
(0.053)\end{array}$ & $\begin{array}{l}0.287^{* *} \\
(0.114)\end{array}$ & $\begin{array}{l}0.350^{* * *} \\
(0.096)\end{array}$ & $\begin{array}{l}0.326^{* * *} \\
(0.122)\end{array}$ & $\begin{array}{l}0.328^{* * *} \\
(0.091)\end{array}$ & $\begin{array}{l}0.356^{* * *} \\
(0.077)\end{array}$ & $\begin{array}{l}0.436^{* * *} \\
(0.069)\end{array}$ & $\begin{array}{c}0.415^{* * *} \\
(0.118)\end{array}$ & $\begin{array}{l}0.394^{* * *} \\
(0.083)\end{array}$ & $\begin{array}{l}0.508^{* * *} \\
(0.090)\end{array}$ \\
\hline TEN & $\begin{array}{l}0.040^{* * *} \\
(0.012)\end{array}$ & $\begin{array}{l}0.044^{* * *} \\
(0.012)\end{array}$ & $\begin{array}{l}0.030^{* *} \\
(0.012)\end{array}$ & $\begin{array}{c}0.015 \\
(0.014)\end{array}$ & $\begin{array}{c}0.012 \\
(0.014)\end{array}$ & $\begin{array}{c}0.001 \\
(0.015)\end{array}$ & $\begin{array}{l}0.024^{* *} \\
(0.012)\end{array}$ & $\begin{array}{l}0.029^{*} \\
(0.015)\end{array}$ & $\begin{array}{c}0.016 \\
(0.012)\end{array}$ & $\begin{array}{l}0.038^{* * *} \\
(0.014)\end{array}$ & $\begin{array}{l}0.045^{* * *} \\
(0.014)\end{array}$ & $\begin{array}{c}0.024^{*} \\
(0.014)\end{array}$ \\
\hline SQTEN & $\begin{array}{c}0.001 \\
(0.001)\end{array}$ & $\begin{array}{c}0.001 \\
(0.001)\end{array}$ & $\begin{array}{l}0.002^{* *} \\
(0.001)\end{array}$ & $\begin{array}{l}0.003^{* *} \\
(0.001)\end{array}$ & $\begin{array}{l}0.003^{* *} \\
(0.001)\end{array}$ & $\begin{array}{l}0.004^{* * *} \\
(0.001)\end{array}$ & $\begin{array}{l}0.002^{* *} \\
(0.001)\end{array}$ & $\begin{array}{c}0.002 \\
(0.001)\end{array}$ & $\begin{array}{l}0.003^{* * *} \\
(0.001)\end{array}$ & $\begin{array}{c}0.001 \\
(0.001)\end{array}$ & $\begin{array}{c}0.001 \\
(0.001)\end{array}$ & $\begin{array}{l}0.003^{* * *} \\
(0.001)\end{array}$ \\
\hline Height & $\begin{array}{c}-0.009^{* * *} \\
(0.003)\end{array}$ & $\begin{array}{c}-0.009^{* * *} \\
(0.003)\end{array}$ & $\begin{array}{c}-0.019^{* * *} \\
(0.003)\end{array}$ & $\begin{array}{c}-0.011^{* * *} \\
(0.004)\end{array}$ & $\begin{array}{c}-0.009^{* * *} \\
(0.003)\end{array}$ & $\begin{array}{c}-0.015^{* * *} \\
(0.003)\end{array}$ & $\begin{array}{c}-0.015^{* * *} \\
(0.002)\end{array}$ & $\begin{array}{c}-0.016^{* * *} \\
(0.003)\end{array}$ & $\begin{array}{c}-0.020^{* * *} \\
(0.004)\end{array}$ & $\begin{array}{c}-0.014^{* * *} \\
(0.003)\end{array}$ & $\begin{array}{c}-0.016^{* * *} \\
(0.004)\end{array}$ & $\begin{array}{c}-0.022^{* * *} \\
(0.004)\end{array}$ \\
\hline Weight & $\begin{array}{l}0.003^{*} \\
(0.002)\end{array}$ & $\begin{array}{l}0.003^{*} \\
(0.002)\end{array}$ & $\begin{array}{l}0.008^{* * *} \\
(0.002)\end{array}$ & $\begin{array}{c}0.003 \\
(0.003)\end{array}$ & $\begin{array}{c}0.001 \\
(0.002)\end{array}$ & $\begin{array}{l}0.006^{* * *} \\
(0.002)\end{array}$ & $\begin{array}{c}0.003 \\
(0.002)\end{array}$ & $\begin{array}{c}0.003 \\
(0.002)\end{array}$ & $\begin{array}{l}0.007^{* * *} \\
(0.003)\end{array}$ & $\begin{array}{c}0.004 \\
(0.003)\end{array}$ & $\begin{array}{l}0.005^{* *} \\
(0.002)\end{array}$ & $\begin{array}{l}0.012^{* * *} \\
(0.003)\end{array}$ \\
\hline Performance & YES & YES & YES & YES & YES & YES & YES & YES & YES & YES & YES & YES \\
\hline PIT & & YES & YES & & YES & YES & & YES & YES & & YES & YES \\
\hline HIT & & YES & YES & & YES & YES & & YES & YES & & YES & YES \\
\hline POS & & YES & YES & & YES & YES & & YES & YES & & YES & YES \\
\hline TEAM & & & YES & & & YES & & & YES & & & YES \\
\hline
\end{tabular}

Table 3 Continued

\begin{tabular}{|c|c|c|c|c|c|c|c|c|c|c|c|c|}
\hline League & & & YES & & & YES & & & YES & & & YES \\
\hline Year & & & YES & & & YES & & & YES & & & YES \\
\hline _cons & $\begin{array}{l}4.214^{* * *} \\
(0.444)\end{array}$ & $\begin{array}{c}4.188^{* * *} \\
(0.451)\end{array}$ & $\begin{array}{c}4.835 \\
(0.447)\end{array}$ & $\begin{array}{c}4.421^{* * *} \\
(0.542)\end{array}$ & $\begin{array}{l}4.349^{* * *} \\
(0.437)\end{array}$ & $\begin{array}{c}4.999^{* * *} \\
(0.538)\end{array}$ & $\begin{array}{c}5.317^{* * *} \\
(0.406)\end{array}$ & $\begin{array}{l}5.347^{* * *} \\
(0.372)\end{array}$ & $\begin{array}{l}5.845^{* * *} \\
(0.546)\end{array}$ & $\begin{array}{c}5.157^{* * *} \\
(0.446)\end{array}$ & $\begin{array}{l}5.250^{* * *} \\
(0.509)\end{array}$ & $\begin{array}{c}5.863^{* * *} \\
(0.513)\end{array}$ \\
\hline (Pseudo)-R ${ }^{2}$ & 0.588 & 0.593 & 0.633 & 0.351 & 0.356 & 0.396 & 0.432 & 0.438 & 0.477 & 0.452 & 0.460 & 0.495 \\
\hline
\end{tabular}

Notes: (a) Standard errors are in parentheses; (b) ${ }^{* * *}$ denotes significance at the $1 \%$ level, ${ }^{* *}$ denotes significance at the $5 \%$ level, and ${ }^{*}$ denotes significance at the $10 \%$ level.

years and decreases thereafter (the coefficients of TEN and SQTEN in the third column). ${ }^{9}$ However, a player's salary in the low quantile increases at an increasing rate as tenure increases. This means lower-salary players enjoy an increasing rate of salary rises, and it appears puzzling that the tenure effect changes as a player's salary reaches different levels. ${ }^{10}$

For the analysis of marginal effect, on average, NPB managers pay international players $54.7 \%-57.3 \%$ more than domestic players with similar characteristics. Compared to the separate regressions by game season pre-

${ }^{8}$ Other things being equal, the turning point of the tenure effect (from positive to negative) is 23.25 to 24.75 years for the median quantile according to the Quantile estimation. Moreover, Figures 2(e) and (f) plot the details of coefficient and confidence interval for the effects of tenure and its square term. A positive slope for the tenure coefficient in different quantiles of salary is revealed, but the slope of its square term is negative. It reveals an optimal tenure for a professional baseball player in his career.

${ }^{10}$ Many different combinations of performance as regressors were used, and the results remain similar. The results of performance effect can be provided by the author if needed. sented in [1], the results in the NPB are a little bit higher than their coefficient (51.9\%) in NBA's estimation.

The results of QR indicate that the marginal effects range from $0.485-0.529$ for the lower quantile and 0.698 - 0.773 for the higher quantile. That is, international players with a relatively low salary are paid $48.5 \%$ $52.9 \%$ more than Japanese players, and international players with a relatively high salary are paid $69.8 \%$ $77.3 \%$ more than domestic Japanese players. The nationality effect increases with salary. Figure 2(b) plots the details of the coefficient and confidence interval for the effect of nationality, and a positive slope for the nationality coefficient in different quantiles of salary are presented. Meanwhile, Figure 2(a)-(f) shows the details for the effects of tenure, height, and weight on salary.

The interesting findings in quantile regression show that salary premium increases when an international player's salary increases. This finding may reveal the differing employees' reservation salaries from different countries. In the NPB league, the international players 
Table 4. Estimation results of ols and quantile regressions for pitchers $(n=1225)$.

\begin{tabular}{|c|c|c|c|c|c|c|c|c|c|c|c|c|}
\hline \multirow[t]{2}{*}{ LogSal } & \multicolumn{3}{|c|}{ OLS } & \multicolumn{9}{|c|}{ Quantile } \\
\hline & & & & & 25 th & & & 50 th & & & 75th & \\
\hline Nat & $\begin{array}{l}0.222^{* * *} \\
(0.046)\end{array}$ & $\begin{array}{l}0.225^{* * *} \\
(0.046)\end{array}$ & $\begin{array}{l}0.219^{* * *} \\
(0.045)\end{array}$ & $\begin{array}{l}0.246^{* * *} \\
(0.042)\end{array}$ & $\begin{array}{l}0.240^{* * *} \\
(0.082)\end{array}$ & $\begin{array}{l}0.225^{* * *} \\
(0.074)\end{array}$ & $\begin{array}{l}0.231^{* * *} \\
(0.054)\end{array}$ & $\begin{array}{l}0.245^{* * *} \\
(0.067)\end{array}$ & $\begin{array}{l}0.244^{* * *} \\
(0.059)\end{array}$ & $\begin{array}{l}0.149^{* *} \\
(0.065)\end{array}$ & $\begin{array}{l}0.237^{* * *} \\
(0.084)\end{array}$ & $\begin{array}{l}0.198^{* * *} \\
(0.074)\end{array}$ \\
\hline TEN & $\begin{array}{l}0.082^{* * *} \\
(0.011)\end{array}$ & $\begin{array}{l}0.082^{* * *} \\
(0.011)\end{array}$ & $\begin{array}{l}0.092^{* * *} \\
(0.011)\end{array}$ & $\begin{array}{l}0.053^{* * *} \\
(0.013)\end{array}$ & $\begin{array}{l}0.054^{* * *} \\
(0.016)\end{array}$ & $\begin{array}{l}0.053^{* * *} \\
(0.015)\end{array}$ & $\begin{array}{l}0.083^{* * *} \\
(0.013)\end{array}$ & $\begin{array}{l}0.085^{* * *} \\
(0.012)\end{array}$ & $\begin{array}{l}0.094^{* * *} \\
(0.009)\end{array}$ & $\begin{array}{l}0.106^{* * *} \\
(0.012)\end{array}$ & $\begin{array}{l}0.103^{* * *} \\
(0.008)\end{array}$ & $\begin{array}{l}0.119^{* * *} \\
(0.010)\end{array}$ \\
\hline SQTEN & $\begin{array}{c}-0.002^{* *} \\
(0.001)\end{array}$ & $\begin{array}{c}-0.002^{* *} \\
(0.001)\end{array}$ & $\begin{array}{c}-0.003^{* * *} \\
(0.001)\end{array}$ & $\begin{array}{c}-0.0002 \\
(0.001)\end{array}$ & $\begin{array}{c}-0.0003 \\
(0.002)\end{array}$ & $\begin{array}{l}0.0003 \\
(0.001)\end{array}$ & $\begin{array}{c}-0.002^{*} \\
(0.001)\end{array}$ & $\begin{array}{l}-0.002^{*} \\
(0.001)\end{array}$ & $\begin{array}{c}-0.003^{* * *} \\
(0.001)\end{array}$ & $\begin{array}{c}-0.004^{* * *} \\
(0.001)\end{array}$ & $\begin{array}{c}-0.004^{* * *} \\
(0.001)\end{array}$ & $\begin{array}{c}-0.005^{* * *} \\
(0.001)\end{array}$ \\
\hline Height & $\begin{array}{c}-0.011^{* * *} \\
(0.002)\end{array}$ & $\begin{array}{c}-0.011^{* * *} \\
(0.002)\end{array}$ & $\begin{array}{c}-0.009^{* * *} \\
(0.002)\end{array}$ & $\begin{array}{c}-0.018^{* * *} \\
(0.004)\end{array}$ & $\begin{array}{c}-0.018^{* * *} \\
(0.003)\end{array}$ & $\begin{array}{c}-0.011^{* * *} \\
(0.003)\end{array}$ & $\begin{array}{c}-0.012^{* * *} \\
(0.003)\end{array}$ & $\begin{array}{c}-0.011^{* * *} \\
(0.002)\end{array}$ & $\begin{array}{c}-0.010^{* * *} \\
(0.003)\end{array}$ & $\begin{array}{l}-0.006 \\
(0.004)\end{array}$ & $\begin{array}{c}-0.007^{* *} \\
(0.003)\end{array}$ & $\begin{array}{l}-0.006^{*} \\
(0.004)\end{array}$ \\
\hline Weight & $\begin{array}{l}0.009^{* * *} \\
(0.002)\end{array}$ & $\begin{array}{c}0.008^{* * *} \\
(0.002)\end{array}$ & $\begin{array}{l}0.008^{* * *} \\
(0.002)\end{array}$ & $\begin{array}{l}0.010^{* * *} \\
(0.002)\end{array}$ & $\begin{array}{l}0.010^{* * *} \\
(0.002)\end{array}$ & $\begin{array}{c}0.007^{* * *} \\
(0.002)\end{array}$ & $\begin{array}{l}0.009^{* * *} \\
(0.002)\end{array}$ & $\begin{array}{c}0.009^{* * *} \\
(0.002)\end{array}$ & $\begin{array}{c}0.009^{* * *} \\
(0.002)\end{array}$ & $\begin{array}{l}0.009^{* * *} \\
(0.002)\end{array}$ & $\begin{array}{l}0.009^{* * *} \\
(0.002)\end{array}$ & $\begin{array}{l}0.008^{* * *} \\
(0.003)\end{array}$ \\
\hline Performance & YES & YES & YES & YES & YES & YES & YES & YES & YES & YES & YES & YES \\
\hline PIT & & YES & YES & & YES & YES & & YES & YES & & YES & YES \\
\hline HIT & & YES & YES & & YES & YES & & YES & YES & & YES & YES \\
\hline POS & & YES & YES & & YES & YES & & YES & YES & & YES & YES \\
\hline TEAM & & & YES & & & YES & & & YES & & & YES \\
\hline League & & & YES & & & YES & & & YES & & & YES \\
\hline Year & & & YES & & & YES & & & YES & & & YES \\
\hline _cons & $\begin{array}{l}4.131^{* * *} \\
(0.362)\end{array}$ & $\begin{array}{l}4.187^{* * *} \\
(0.365)\end{array}$ & $\begin{array}{l}3.931^{* * *} \\
(0.369)\end{array}$ & $\begin{array}{l}5.201^{* * *} \\
(0.655)\end{array}$ & $\begin{array}{l}5.213^{* * *} \\
(0.450)\end{array}$ & $\begin{array}{l}4.260 \\
(0.437)\end{array}$ & $\begin{array}{l}4.306^{* * *} \\
(0.479)\end{array}$ & $\begin{array}{l}4.146^{* * *} \\
(0.405)\end{array}$ & $\begin{array}{l}3.926^{* * *} \\
(0.452)\end{array}$ & $\begin{array}{c}3.414 \\
(0.614)\end{array}$ & $\begin{array}{c}3.492 \\
(0.459)\end{array}$ & $\begin{array}{l}3.570^{* * *} \\
(0.560)\end{array}$ \\
\hline (Pseudo)-R ${ }^{2}$ & 0.501 & 0.506 & 0.552 & 0.265 & 0.267 & 0.308 & 0.320 & 0.323 & 0.364 & 0.364 & 0.369 & 0.401 \\
\hline
\end{tabular}

Notes: (a) Standard errors are in parentheses; (b) ${ }^{* * *}$ denotes significance at the $1 \%$ level, ${ }^{* *}$ denotes significance at the $5 \%$ level, and ${ }^{*}$ denotes significance at the $10 \%$ level.

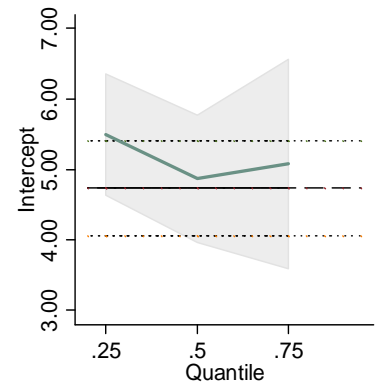

(a)

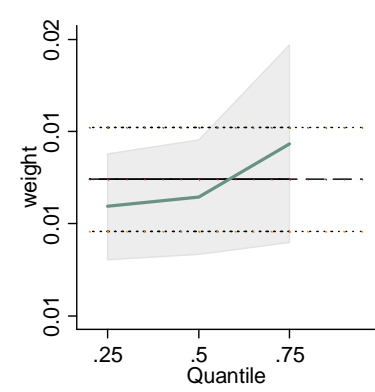

(d)

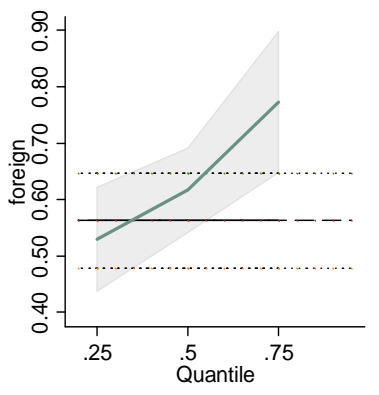

(b)

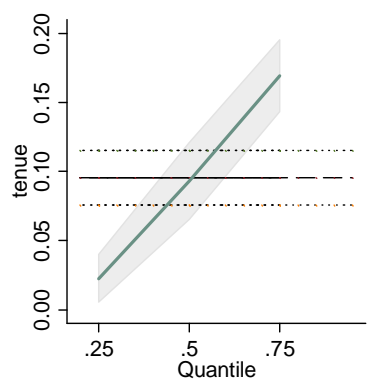

(e)

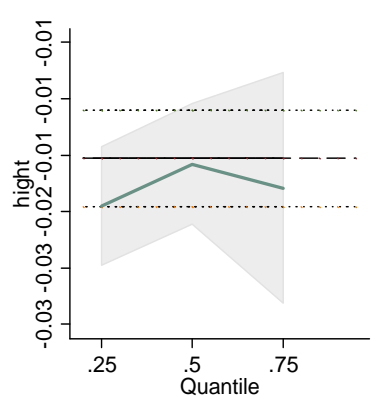

(c)

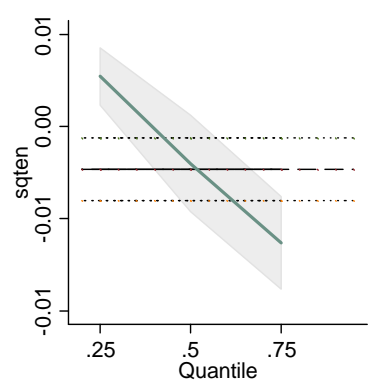

(f)

Figure 2 Coefficients of OLS and Quantile regressions with related Confidence intervals by each variable Notes: a) Black solid line is plotted by the OLS results, and the black dotted line includes its $\mathbf{9 0 \%}$ confidence interval; b) Color solid line is plotted by the QR results, and the gray band includes its $90 \%$ confidence interval. 
mainly came from America (56.41\%), Chinese Taipei, and the Dominican Republic. The distribution is presented as a pie chart in Figure 3. These main international players' average salaries in the NPB are showed in Figure 4. International players are apt to accept offers when the offer is much higher than what their home countries pay. Therefore, the nationality premium may differ when NPB teams "import" their players from different countries. Employees' reservation salaries from different countries can result in the different salary premiums based on nationality. However, more empirical works is needed to investigate the relationship between nationality premiums and employees' reservation salaries. This would appear to be a fruitful area for future research. ${ }^{11}$

\section{Conclusions}

In this paper OLS regression and QR are employed to investigate the salary discrimination by nationality in the NPB. Data from 14 NPB teams including 322 batters and 341 pitchers over the 9-year period from 2000 to 2008 was collected. The main finding of this study indicates that, even the player's performance is controlled, international players were paid significantly more than domestic players ceteris paribus. Compared to Japanese players, the observed salary premium is $54.7 \%-57.3 \%$ for international players on average. The team may overestimate an international player's MRP for two reasons. One is NPB employer's limited information about players. The other is the trade uncertainty difference caused by the different regulations for domestic and international play-

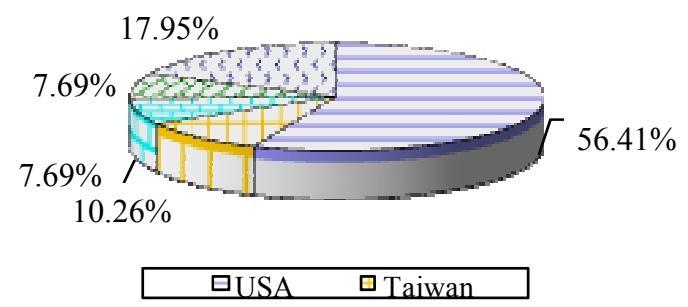

Figure 3. Distribution of international players by nationality in the NPB.

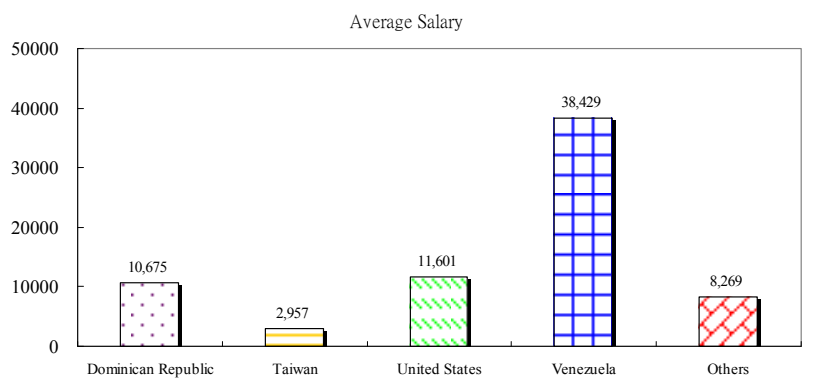

Figure 4. International players' average salary in the NPB.

${ }^{11}$ The hypothesis of employee's reservation salary is important and it is less discussed in the literature. ers in the free agent market.

Moreover, in the QR results, the positive effect of nationality on salary is larger for players with relatively high salaries. Low-salary international players are paid $48.5 \%-52.9 \%$ more than Japanese players, and highsalary. International players are paid $69.8 \%-77.3 \%$ more than domestic Japanese players. The nationality premium increases with salary.

As to the tenure effect, on average, a player's salary increases at a decreasing rate as tenure increases. But, the salary of a player in a lower quantile increases at an increasing rate as tenure increases. It appears puzzling that the growth of tenure effect for low-salary players is much stronger than average. As the efficiency wage hypothesis argues, in order to increase players' productivity or efficiency, managers have incentives to pay their players more, especially for low-salary and high-potential young workers. Hence, the positive increasing rate of tenure effect for low-salary players reveals that they enjoy a rising salary at an increasing rate.

\section{REFERENCES}

[1] E. Eschker, S. Perez and M. Siegler, "The NBA and the Influx of International Basketball Players," Applied Economics, Vol. 36, No. 10, 2004, pp. 1009-1020. doi:10.1080/0003684042000246713

[2] J. Gwartney and C. Haworth, "Employer Costs and Discrimination: The Case of Baseball," Journal of Political Economy, Vol. 82, No. 4, 1974, pp. 873-881. doi:10.1086/260241

[3] M. T. Kanazawa and J. P. Funk, "Racial Discrimination in Professional Basketball: Evidence from Nielsen Ratings," Economic Inquiry, Vol. 39, No. 4, 2001, pp. 599608. doi:10.1093/ei/39.4.599

[4] S. Szymanski, "A Market Test for Discrimination in the English Professional Soccer Leagues," Journal of Political Economy, Vol. 108, No. 3, 2000, pp. 590-603. doi: $10.1086 / 262130$

[5] D. P. Wilson and Y. H. Ying, "Nationality Preferences for Labor in the International Football Industry," Applied Economics, Vol. 35, No. 14, 2003, pp. 1551-1559. doi: $10.1080 / 000368403200010048$

[6] R. Pedace, "Earnings, Performance, and Nationality Discrimination in a Highly Competitive Labor Market: An Analysis of the English Professional Soccer League." Journal of Sports Economics, Vol. 9, No. 2, 2008, pp. 115-140. doi: $10.1177 / 1527002507301422$

[7] G. Becker, "The Economics of Discrimination," 2nd Edition, University of Chicago Press, Chicago, 1971.

[8] G. W. Scully, "Economic Discrimination in Professional Sports," Law and Contemporary Problems, Vol. 38, No. 1, 1973, pp. 67-84.

[9] H. Raimondo, "Free Agents' Impact on the Labor Market for Baseball Players," Journal of Labor Research, Vol. 4, No. 2, 1983, pp. 183-193. doi:10.1007/BF02685176 
[10] J. R. Hill and W. Spellman, "Pay Discrimination in Baseball: Data from the Seventies," Industrial Relations, Vol. 23, No. 1, 1984, pp. 103-112. doi:10.1111/j.1468-232X.1984.tb00879.x

[11] K. J. Christiano, "Salary Discrimination in Major League Baseball: The Effect of Race," Sociology of Sport Journal, Vol. 3, No. 2, 1988, pp. 144-153.

[12] K. J. Christiano, "Salaries and Race in Professional Baseball: Discrimination 10 Years Later," Sociology of Sport Journal, Vol. 5, No. 2, 1986, pp. 136-149.

[13] O. B. Bodvarsson and S. P. Pettman, "Racial Wage Discrimination in Major League Baseball: Do Free Agency and League Size Matter?" Applied Economics Letters, Vol. 9, No. 12, 2002, pp. 791-796. doi:10.1080/13504850210135714

[14] E. Brown, R. Spiro and D. Keenan, "Wage and Nonwage Discrimination in Professional Basketball: Do Fans Affect It?" American Journal of Economics and Sociology, Vol. 50, No. 3, 1991, pp. 333-345. doi:10.1111/j.1536-7150.1991.tb02300.x

[15] L. M. Kahn and P. D. Sherer, "Racial Differences in Professional Basketball Players' Compensation," Journal of Labor Economics, Vol. 6, No. 1, 1988, pp. 40-61. doi:10.1086/298174

[16] B. H. Hamilton, "Racial Discrimination and Professional Basketball Salaries in the 1990s," Applied Economics, Vol. 29, No. 3, 1997, pp. 287-296. doi:10.1080/000368497327065

[17] I. Preston and S. Szymanski, "Racial Discrimination in English Football," Scottish Journal of Political Economy, Vol. 47, No. 4, 2000, pp. 342-63. doi:10.1111/1467-9485.00168
[18] J. C. H. Jones and W. D. Walsh, "Salary Determination in the National Hockey League: The Effects of Skills, Franchise Characteristics, and Discrimination," Industrial and Labor Relations Review, Vol. 41, No. 4, 1988, pp. 592604. doi: $10.2307 / 2523593$

[19] N. Longley, "Salary Discrimination in the National Hockey League: The Effects of Team Location," Canadian Public Policy, Vol. 21, No. 4, 1995, pp. 413-422.

[20] N. Longley, "The Effects of Inter-League Competition on Labor Market Discrimination: Assessing the Impacts of the World Hockey Association," The Social Science Journal, Vol. 40, No. 4, 2003, pp. 651-656. doi:10.1016/S0362-3319(03)00076-4

[21] G. W. Scully, "The Economics of Discrimination in Professional Sports: The Case of Baseball," Paper Prepared for a Conference on Government and the Sports Business, 6 and 7 December 1971.

[22] A. H. Pascal and L. A. Rapping, "The Economics of Racial Discrimination in Organized Baseball," In: A. H. Pascal, Ed., Racial Discrimination in Economic Life, D.C. Heath, Lexington, 1972, pp. 119-156.

[23] L. M. Kahn, "Managerial Quality, Team Success, and Individual Player Performance in Major League Baseball," Industrial and Labor Relations Review, Vol. 46, No. 3, 1993, pp. 531-547. doi:10.2307/2524551

[24] R. Koenker and G. S. Bassett, "Regression Quantile," Econometrica, Vol. 46, No. 1, 1978, pp. 33-50. doi: $10.2307 / 1913643$

[25] R. Koenker, "Quantile Regression," Cambridge University Press, Cambridge, No. 38, 2005. doi:10.1017/CBO9780511754098 